\title{
CRITICAL GENRE ANALYSIS AND PROFESSIONAL PRACTICE: THE CASE OF PUBLIC CONTESTS TO SELECT PROFESSORS FOR BRAZILIAN PUBLIC UNIVERSITIES
}

\begin{abstract}
Adair Bonini*
Abstract: Several approaches have been applied to the analysis of language at work, among them, the ergologic (LACOSTE, 1998; NOUROUDINE, 2002), the interactional-sociolinguistic (DREW, HERITAGE, 1992), and the genre-based (BAZERMAN; PARADIS, 1991). In this article, focusing on the latter approach, I discuss the reasons and methods for analyzing professional genres. Particularly, I center my attention on the approach which, more recently, has been called critical genre analysis (BHATLA, 2004, 2007, 2009; MOTTA-ROTH, 2008). As part of the theoretical reflection undertaken, I also present an introductory analysis of genres involved in the social practice of public contests for professor positions at Brazilian universities. These examinations not only exemplify a kind of problematic relation between language and work, but they constitute an excellent example to illustrate a Critical Genre Analysis (CGA).

Keywords: Genre. Professional practice. Critical analysis. Employee selection. Public contest.
\end{abstract}

\section{INTRODUCTION}

"Language at work" is already a recognized field of study within the larger area of Applied Linguistics. The research carried out around this theme focuses, generally, on how language participates in the performance of professional tasks, creating environments, identities, social relations, etc. This is a field that can be approached from many perspectives, one of which is genre analysis.

In this work, I try to discuss the contribution of genre analysis to the study of the relation between language and work. The discussion developed here aims, more specifically, to reflect on a particular perspective on genre analysis, the critical one (BHATIA, 2004, 2007; MOTTA-ROTH, 2008).

\footnotetext{
*PhD in Linguistics, Universidade Federal de Santa Catarina, Brazil. Email: adbonini@yahoo.com.br.
} 
To illustrate the critical perspective to the study of genres as professional practice, I report findings from a study on public contests to select professors at Brazilian Federal universities. In Brazil, job positions in government agencies and state institutions are filled by professionals selected through public contests. In general theses contests, due to the high number of applicants, are carried out through multiple choice tests. Professors at public universities, however, are usually selected via a specific kind of contest which comprises, for example, teaching demonstration and curriculum evaluation.

\section{GENRE AND PROFESSIONAL PRACTICES}

Among the various perspectives used to investigate the language/work relationship, we can mention:

a) the interactional sociolinguistic approach (DREW; HERITAGE, 1992), which seeks to describe the speech events based, for example, on footing theory (GOFFMAN, 1979). Among the works in this area we also find those which incorporate a critical discourse perspective (OSTERMANN; SOUZA, 2009; HALL; SLEMBROUCK; SARANGI, 2006);

b) the ergological approach (LACOSTE, 1998; NOUROUDINE, 2002), which seeks to identify the conditions under which work problems can be reinterpreted;

c) the critical discourse analysis approach (FAIRCLOUGH, 1993; GEE; HULL; LANKSHEAR, 1996), which has especially privileged, in recent years, issues related to globalization, focusing on the representations and practices that constitutes work; and

d) the genre analysis approach (BAZERMAN; PARADIS, 1991; BHATIA, 1993, 2004; DEVITT, 1991; SWALES, 1998) which seeks to determine the role of texts in the constitution of professional practices.

The analysis of professional genres, the theoretical view adopted here, does not differ greatly from the analysis of other specific king of genres (those of art, school, science, etc.). But there are specific elements of the language/work studies tradition which must be considered, such 
as the distinction between "effective practice" and "prescribed practice", which is better explained in Naroudine (2002) and Lacoste (1998) who, based on Johnson and Kaplan (1979), established the distinctions between: language about work (the prescription); language as work (intrinsic to the professional practice); and, finally, language at work (surrounding the work practices).

In recent years, a particular perspective has emerged in genre studies, the Critical Genre Analysis (hereafter CGA), resulting from the fusion of two fields: Genre Analysis and Critical Discourse Analysis. The worlds of research on genre and discourse have become closer in recent years. As Motta-Roth (2008) says:

In the case of Genre Analysis, Bakhtin and Fairclough, initially absent, appear in the more recent books of Swales $(1990,2004)$ and Bhatia $(1993,2004)$. [...] [And] if the sociological or sociohistorical thought represented by Fairclough has been settling in the discussions on genre, the use of the word "genre" by Fairclough has also become increasingly frequent. Used as a tool for theorizing and explanation, "genre" appears in an increasing number of pages in the table of contents of Fairclough's works over the years. (p. 354)

This connection between Critical Discourse Analysis (FAIRCLOUGH, 2003) and Genre Analysis has given rise to Critical Genre Analysis (CGR), a view suggested in Bhatia (2004) and explicitly assumed in his later works $(2007,2008$, and this volume). It was also discussed by Motta-Roth (2008).

In his 2004 work, Bhatia advocates a critical approach to the study of genre, which is already manifested when he presents the history of written discourse studies. In an evolutionary perspective, he conceives the history of this field as accomplished in three stages (textualization, organization and contextualization). Furthermore, he points out as the last item of third stage the studies of "language as critical discourse, language as social control, and language in and as social interaction." In this book, he also proposes a multidimensional and multiple perspective model to the study of written discourse (BHATIA, 2004, p. 19) which includes, in an overlapping way, three spaces of analysis: a) the textual 
(where one can analyze discourse as text and as textual knowledge), b) the social-cognitive (where discourse can be analyzed, on the one hand, as genre and genre knowledge and, on the other, as professional practice and professional expertise), and c) the social (where discourse can be analyzed as social practice and as social and pragmatic knowledge).

In a more recent article, Bhatia (2007) presents three examples of analysis which focus on interdiscursivity and asymmetrical power relations: a) the colonization of accounting discourse by public relations discourse within the "annual report", a corporate disclosure genre; b) the colonization of arbitration practices by litigation, affecting the genres related to the former, and c) the appropriation of the philanthropic culture of charitable campaigns by advertising culture and genres. In this article, through these examples, he advocates CGA, as can be seen in this passage:

The paper argues for a critical study of discursive activities of professional cultures by focusing on 'interdiscursivity' as interaction between discursive and professional practices in the context of specific professional, corporate and institutional cultures, which I would like to characterize as a move towards critical genre analysis. (p. 399)

In a 2008 work, Motta-Roth also makes a defense of CGA. She takes Bhatia's (2004) work as the initial base of her reflection on the issue. She also presents several examples of CGA, the most instructive of which being, in my view, the research of Al-Ali (2006) regarding Jordanian wedding invitations and how this genre, within the Muslim context, "emphasizes male authority and erases feminism" (MOTTAROTH, p. 361).

This relation between Genre Analysis and Critical Discourse Analysis seems to be a point of discussion that will still yield considerable debate and which has been outlined differently in Bhatia's 2004 and 2007 works, for example. In 2004 (p. 19), he proposed two opposite poles: on the one hand, the educational perspective (bottomup), which starts in the text going towards the social practice; on the other hand, the socio-critical perspective (top-down), going from the 
social practice to the text. In 2007, Bhatia, considering text, genre, professional practice and professional culture, argues that there are two continuums: from text to context and from discursive to professional practice. In both cases, moving beyond a genre analysis focused on textual organization, external aspects are considered - those related to social practices, as conceived by Fairclough (2003). In this sense, Bhatia (2007) states: "Text-external resources include the conventions that constrain generic constructs as well as professional practices, and perhaps more appropriately, specific disciplinary cultures that motivate these practices, both discursive as well as professional practices" (p. 392 - italics added).

In a previous work (BONINI, 2009), inspired mainly in Fairclough (2003) and Bhatia (2004), I presented a conceptual framework [Fig. 1] in which the dimensions of the study of genre and discourse can be viewed in a certain way. This figure consists of the following levels:

a) social structure - understood, similarly to Fairclough (2003), as an abstract entity (like the church, economics, social classes, etc.) comprising a set of possibilities of social practices and genres, and giving rise to one-more discourses;

b) discourse - the representation of views of the world, identities and relationships which reproduces and at the same time constitutes the social structure, the social practice and thus their genres;

c) genre - a set of typical actions of textualization, text production and comprehension, which performs at least one social practice within various possible relational chains, carrying out then the discourse and the social structure. The types of relationships within which social practices and genres exist in relation to each other are: i) hypergeneric (genres in relation to other genres, composing a higher genre), ${ }^{1}$ ii) mediatic (genres in relation to the mediation unit that makes them circulate in society), iii) systemic (genres in relation to other genres, creating a specific social routine), and iv) community (genres in relation to other genres, according to the distribution of roles within the discourse community).

\footnotetext{
${ }^{1}$ To know more about the term "hypergenre", see Bonini (2008); to the term "system of genre", see Bazerman (1994), and to "discourse community", Swales (1998).
} 


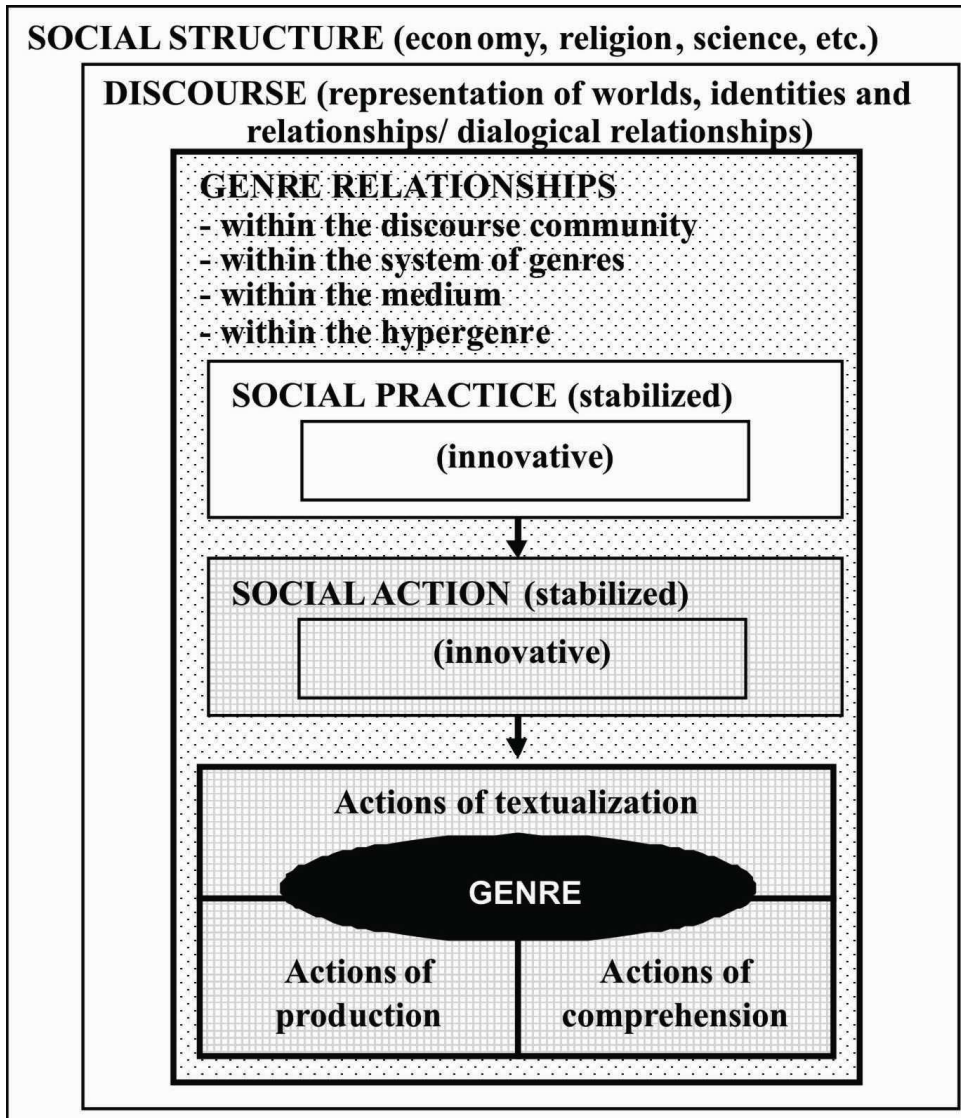

Figure 1 - Levels in genre and discourse analysis (BONINI, 2009).

If considered from a bottom-up perspective (from the actions of comprehension, production and textualization of genres as well as from genre relationships), this figure shows the genre analysis. If considered downwardly (starting from the social structure, the representation of worlds, identities and relationships, and the clash of voices), it shows the analysis of discourse. A middle term between these two pathways corresponds to CGA, since CGA, although focusing on a genre, selects this genre according to a discourse problem (relational or identity issues 
and the clash of voices). Critical genre analysis shares the view of Fairclough (2003), but also of Blyler (1998), that the analysis of language can (and does) occur as a social act, as a way to participate in the discussion and solution of social problems.

In terms of methodology, the research in CGA has the object identification and delimitation driven by social problems which must be determined and considered previously. In a subsequent phase, to demonstrate the role of a genre in the questioned practice, the researcher can delimit the object (in this case the genre/s), regarding its modes of production, understanding and textualization, as well as considering the relationships in terms of the genre itself (when several genres are combined to compose a larger unit of interaction - a hypergenre), in terms of the media, or genre system, or discourse community.

The procedures for the analysis of genres, as well as the analysis of discourses, are determined and implemented according to the needs of the object under investigation and to the contingencies of the research environment. One can speak thus of an "entry in the data" similar to ethnographers' entry in the field, because a certain amount of negotiation is required.

Finally, it is important emphasize that, in terms of CGA in professional environments, the researcher must take into consideration a whole body of discussion about the language/work relationship carried out in numerous studies based in different approaches, and thus it is required from the researcher some effort (even of intellectual improvement) to master the field.

Regarding the study of genre in work situations, we can consider the existence of three approaches:

a) genre analysis itself (genre + genre components), which describes aspects related to the genre textualization which may involve describing ways of reading and writing, text organization, and genre relationships (in a system, for example);

b) critical genre analysis (genre $\rightarrow$ discourse), which studies genre and its components as part of the discussions around a social problem (racism, xenophobia, power asymmetries, etc.); and 
c) critical discourse analysis (discourse $\rightarrow$ genre) in which social problems are studied from the viewpoint of discursive representations and social relationships, where genres or generic components function as tools to demarcate the context.

In the discussion that follows I take the second position. I start now an analysis of the public contests used to select professors at Brazilian universities. I am considering, firstly, that this is a problematic social practice (both in terms of social identities and relationships) and, secondly, that it is a social practice in which several genres take part (each producing specific social practices as they are textualized through actions of textualization, comprehension and production). In the sections that follow, though I take a critical point of view with respect to these examinations, I do not mean that I am against this form of evaluation and selection of professionals, which is certainly the most democratic, but which needs to be improved and treated very seriously.

\section{THE PUBLIC CONTESTS TO SELECT PROFESSORS FOR BRAZILIAN PUBLIC UNIVERSITIES}

The public contests for the selection of employees have attracted the attention of Brazilian scholars as a research subject. In a search for dissertations and theses on CAPES' (Coordenação de Aperfeiçoamento de Pessoal de Nível Superior/ Coordination of Improvement of Higher Education Personnel) database, I have found 144 works listed on the keyword "concurso público" (public contest), although among them only five were produced within the field of language studies (SEGAFREDO, 2003; BELTRÃO, 2006; BARBOSA, 2008 FERREIRA, 2008; MARTIN, 2008). Even though none of these studies focus on issues related to genre and discourse, the materials and practices related to public contests have already been used to observe, for example, what are the practices and the professional identities presupposed by such materials, and then by those who hold the decision power (SILVA, 2008).

The contests for professors' selection in Brazilian higher education configure both a professional and a language problem, since they are ambiguous. In the common sense, they are understood, on the 
one hand, as excessively unequal, partial and subjective, but, on the other hand, and contradictorily, there is a belief that they actually measure the knowledge of the individual candidates. The problems raised by a biased assessment like this go beyond an ethical damage because:

a) it impacts the social level since, in many cases, the selected professional is elevated to a position of power in relation to many organizations and milieus. As federal universities in Brazil, in general, participate actively in the proposition and management of public policies in many sectors of society, the hiring of a professor by a large Brazilian federal university has a direct impact on many other universities, foundations, and institutions. It is socially relevant, then, to raise and evaluate the professional profile presupposed by these examinations, answering, for example, what are the current representations of knowledge and of the social function of knowledge, and the representations of the practices that make up the role of a professor; and

b) it impacts the personal level, as the applicant may have his/her professional face damaged, his/her self-esteem impaired, and the progress of his/her career compromised in reason of that exposure to the community of peers and, consequently, to his/her current work environment.

If a problem is the reliability of these controversial examinations for professors in Brazilian public universities, the other problem is the clearly asymmetrical power relation established between evaluators and evaluated. Evaluators have the power to propose, implement, evaluate and redesign the rules, practices and genres involved in this kind of initiation ritual. Those evaluated, however, must submit to the ritual proposed, with the legal right to appeal the decision as the only form of defense, in spite of the loss of vitality of such appeals in reason of the irregularities present in the social practice of contests (the use of nonexplicit assessment criteria, for example) that hinders even further the production of more objective legal decisions. In addition, the subjective condition in which the candidate is stuck leaves him/her quite fragile to express his/her dissatisfaction publicly and/or legally. Besides the possibility of his/her complaint being seen as an act of spite, it could also endanger the frail balance of a number of professional relationships. 
In terms of the relationship between language and work, the public contests for professors at Brazilian federal universities can also be seen as a topic of great importance. If, on the one hand, it exists as a practice of selecting new staff for universities, on the other hand, it represents the first professional activity in these institutions. This is a social practice in which language is central, both in terms of the large number of genres taking part in it and in terms of the representations that are reproduced in achieving these genres, practices and actions. In this context, the question "What is an university professor?" is materialized in practices and actions which are often naturalized, considering, for example, that in many of these universities the contest regulations are often kept unchanged for decades, reflecting the absence of an internal debate on this matter and/or reflecting the minor importance given by those universities to that issue.

For an assessment of the organization of contests in Brazilian federal universities, I conducted a survey of announcements and regulations of contests in ten universities - the two tops ones from each Brazilian region and from different states. To determine the level of development of Brazilian universities and therefore to select the greatest of each region, I considered the number of graduate programs that each one holds. The regions and universities surveyed are:

a) South: UFRGS (Universidade Federal do Rio Grande do Sul) and UFSC (Universidade Federal de Santa Catarina);

b) Southeast. UFMG (Universidade Federal de Minas Gerais) and UFRJ (Universidade Federal do Rio de Janeiro);

c) Midwest. UFMS (Universidade Federal do Mato Grosso do Sul) and UnB (Universidade de Brasília);

d) Northeast: UFC (Universidade Federal do Ceará) and UFPE (Universidade Federal de Pernambuco);

e) North: UFAM (Universidade Federal da Amazônia) and UFPA (Universidade Federal do Pará).

This list is representative of all regions of Brazil, but it does not mean that these are the largest universities in the country, since there is a disparity among regions. Moreover, in the Midwest region, I preferred to include the UFMS, instead of the UFG (Federal University of Goiás), because I considered, "for purposes of this research," the Federal 
District (where $\mathrm{UnB}$ is located) and Goiás as composing territorially the same state.

All announcements collected refer to contests for the position of adjunct professor, which is the focus of this analysis. In Brazilian federal universities there are four kinds of posts for professors to which contest are open: auxiliary professor (which requires short postgraduate course, a kind of a pre-Master's course); assistant professor (which requires a Master's degree); adjunct professor (which requires a doctor's title); and titular professor (which requires a doctor's title plus a long and solid professional experience).

I tried to observe, among the collected announcements and regulations, how the social practice of contests for professors is organized: how and which genres take part in it. I also tried to find which representation of professor underlies the practice of contests (what the organization of the practice could reveal on this aspect) and what kind of power relationship is established between evaluators and candidates to the position. The findings here are still preliminary since they cover only a small part of the corpus under study. They may be relevant, however, to highlight the potentialities of the study of identities and social relationships embedded in the practice of public contests (and other examinations) for professors at universities.

As can be seen in the collected material related to public contests, the whole process is initiated by three types of documents: a) the federal legislation (laws, decrees, normative orders); b) local legislation (resolutions from university councils and administrators); and c) administrative actions (contest authorizing orders; orders of distribution of positions; announcements for application, etc.). On the basis of how the general legislation is interpreted and implemented, two patterns of organization of contests arise: universities which have specific legislation (UFRGS, UFSC, UFMG, UFRJ, UFMS, UFC, UFAM) and those which base their contests only on general legislation (UnB, UFPE, UFPA), carrying out specific adjustments according to each situation via the official announcement that candidates can apply to the teaching position. The universities analyzed, when formatting their contests, adopt three degrees of freedom: 
a) minimum, when the practice is seen as uniform for all departments, which implies a slow change since it involves discussing and changing these internal resolutions (UFRGS, UFSC, UFMG, UFRJ, UFMS, UFC, UFAM);

b) medium, when variations in practice are subject to the preparation of the announcement for application or to a specific department resolution (UnB, UFPE); and

c) maximum, when the variations in practice are open to the decision of the departments, which occurs at UFPA, because determining the contest's specific features (such as what kind and how many examinations will take place, and how they will be scored) is the responsibility of each department, which has the mandate to formulate the plans concerning their contests. The planning of the contest, in this case, is a genre which complements the announcement for application.

Overall, considering all the material examined, federal universities' contests compose a general system of genres [Fig. 2] ranging from the regulation of contests and authorization of the vacancy to the hiring of the selected professional.

\begin{tabular}{|ll}
\hline PRACTICE & GENRE \\
\hline 0) Prescribing the practice & Law \\
& Decree \\
& Normative order \\
& Resolution ... \\
& Request for authorization of vacancy ... \\
1) Signalling the need & Contest authorizing order \\
2) Authorization & Order of distribution of positions ... \\
& Announcement for application ... \\
3) Opening of contest & Application form ... \\
4) Registration & Written test \\
5) Contest & Teaching demonstration (simulated class) ... \\
& Appeal ... \\
6) Shares of defense & Psychiatric notice of mental sanity ... \\
\hline
\end{tabular}

Figure 2 - Practices and genres that contextualize the contest as a social practice composed by specific genres.

In the ten universities examined, there is great variation in the set of examinations to which applicants are submitted [Fig 3]. The 
configuration of the practice of contests, however, generally differs in accordance with the distinct levels of the teaching career in Brazilian federal universities, so that each individual contest does not imply all the examinations listed in Figure 3. Moreover, the practical test is usually applied only in technical areas. On the other hand, for the post of adjunct professor, in reason of its being one of the highest positions in federal universities, most of these examinations are applicable. In Figure 3 , only those highlighted are not applicable at this level.

Observing variation and what occurs most frequently, we can identify here an organizational pattern of contests for professors at these universities. Scoring of titles and teaching demonstration occur for all career levels, and, in reason of what the examined documents reveal, they seem to be universal examinations for the ritual of admission into Brazilian public universities. Besides these two examinations, one or more of the tests listed in Figure 3 can occur, composing the following general model: teaching demonstration + scoring of titles + one or more different examinations.

However, although the scoring of titles appears as universal, it does not seem to have a significant role in the approval and classification of applicants, since the greatest emphasis is given to the teaching demonstration. I could observe, through my own participation in contests or through the observation of the participation of colleagues that, even when no greater weight is given to the teaching demonstration, it is always the decisive factor. This emphasis, moreover, is also perceptible through the variation in the weight of such examinations in the universities considered here [Fig. 4].

Only one university, UFMG, values the scoring of titles openly, while two of them give greater weight to the teaching demonstration, and one of them, UFMS, gives a much greater weight to this examination (weight 4). At UFMG, in the resolution 15/1996 (which rules the contests in that institution), the weights are explained in the following way: 


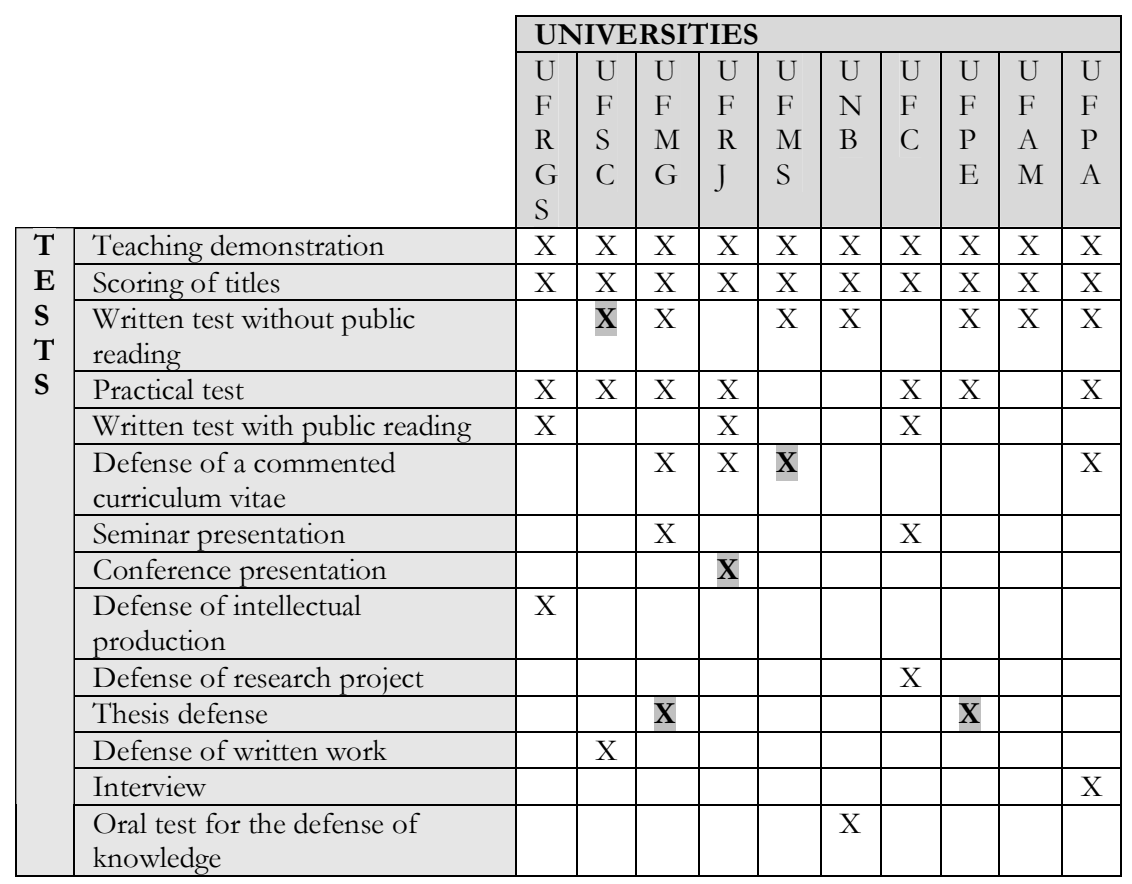

Figure 3-Examinations which compose contests at the universities analyzed (the tests marked with an " $\mathrm{x}$ " highlighted are not applicable for the position of adjunct professor at that university).

\begin{tabular}{|l|r|l|l|r|r|}
\hline University & $\begin{array}{l}\text { Scoring } \\
\text { of titles }\end{array}$ & $\begin{array}{l}\text { Teaching } \\
\text { demonstration }\end{array}$ & University & \multicolumn{1}{|l|}{$\begin{array}{l}\text { Scoring } \\
\text { of titles }\end{array}$} & $\begin{array}{l}\text { Teaching } \\
\text { demonstration }\end{array}$ \\
\hline UFRGS & & & UnB & 1 & 1 \\
\hline UFSC & & & UFC & & $6(?)$ \\
\hline UFMG & 2 & 1 & UFPE & 4 & 2 \\
\hline UFRJ & & & UFAM & 1 & $?$ \\
\hline UFMS & 1 & & UFPA & $?$ & ? \\
\hline
\end{tabular}

Figure 4 - Weights given in the final sum by the universities to the scoring of titles and teaching demonstration ("?" indicates undefined). 
Article 34. Grades will be weighted as follows:

I. in contests for Auxiliary Professor the three grades will have equal weights;

II. in contests for Titular Professor and Assistant Professor, the grade of titles will have weight two, and the other tests will have weight one, according to $₫ 3$ rd in article 116 and $\ 5$ th in article 119 of the General Statute of UFMG;

III. in contests for Adjunct Professor the titles grade will have weight two, and the other examinations, weight one. (Emphasis added)

The UFPE values the scoring of titles, but also establishes a subrule that allows the teaching demonstration to be equal or even more valued than the scoring of titles. The text of the General Statute of UFPE (the basic legislation for contests at that institution) says:

$\S 1$ The scoring of titles will have weight three to the class of Auxiliary Professor and Assistant Professor, and weight four to Adjunct Professor.

$\int 2$ The examinations referred to in item II [written test and/or teaching demonstration or didactic-practical test] shall be defined and will have their weight distributed in accordance with the Statute of Department, taking into account the total of seven to the classes of Auxiliary Professor and Assistant Professor, and six to Adjunct Professor. (Emphasis added)

In all the universities examined, taking into account the weights assigned, it is possible to conclude that the teaching demonstration has a privileged status. One of the most striking examples in this sense is the passage about the weights of examinations present in the resolution $37 / 2008$ of UFMS. The text says: 
Article 22. The examinations of the Public contest for the classes of Auxiliary, Assistant and Adjunct Professor will be:

I - Writing test, weight three;

II - Teaching demonstration, weight four;

III - Scoring of titles, weight one.

Article 23. The examinations of the Public Contest for the Class of Titular Professor will be:

I - Teaching demonstration, weighing four;

II - Defense of Commented Curriculum Vitae, weighing three;

III - Scoring of titles with weight one. (Emphasis added)

It may be noticed in this passage that there is a gradation in which the scoring of titles is given the least important role (with a minimum weight in the set), and, therefore, it seems to me, it can be viewed as the less useful in determining the selection of teachers by this university. Even when the contest is for a titular professor, a position that should be filled by an experienced researcher, the scoring of titles has weight one and the teaching demonstration has weight 4 . The question remains: After years of building a career and having passed through so many contests, must still a titular professor prove (so emphatically) that he/she knows how to give a class? Is his/her experience of so little importance to the university? This emphasis on the teaching demonstration could be viewed as a naïve position or even as an attempt to keep the power of decision centered on the personal judgment of the board (or even the department).

\begin{tabular}{|l|c|l|l|c|c|}
\hline University & $\begin{array}{l}\text { Scoring } \\
\text { of titles }\end{array}$ & $\begin{array}{l}\text { Teaching } \\
\text { demonstration }\end{array}$ & University & $\begin{array}{l}\text { Scoring } \\
\text { of titles }\end{array}$ & $\begin{array}{l}\text { Teaching } \\
\text { demonstration }\end{array}$ \\
\hline UFRGS & $\mathrm{X}$ & & UnB & $\mathrm{X}$ & $\mathrm{X}$ \\
\hline UFSC & $\mathrm{X}$ & & UFC & $\mathrm{X}$ & $\mathrm{X}$ \\
\hline UFMG & & & UFPE & & \\
\hline UFRJ & & & UFAM & $\mathrm{X}$ & $\mathrm{X}$ \\
\hline UFMS & $\mathrm{X}$ & & UFPA & $?$ & $?$ \\
\hline
\end{tabular}

Figure 5 - Universities which have criteria for scoring titles and the teaching demonstration. 
Another interesting aspect regarding how these contests are organized is the fact that although the teaching demonstration is more valued, if compared with the scoring of titles, its nature is not well and openly explained. From the 10 universities considered, only three have criteria for judging the teaching demonstration, against five of them which have criteria for scoring titles [fig. 5]. That is, the applicant, when he/she prepares and teaches his/her class in one of these contests, is not aware at any time of which aspects are being evaluated, which holds greater weight, which holds less weight.

Let us examine the criteria set out to evaluate the teaching demonstration in these three universities. UnB (by the announcement 578/2009) says:

10.11. In the teaching demonstration, the Commission will evaluate and score the candidate regarding:

a) the expertise related to the object of evaluation drawn, with a score equal to 3.0 ;

b) the ability to organize ideas about the object of evaluation drawn, with a score of 2.5;

c) the ability to present ideas about the object of evaluation drawn in a manner appropriate to the student level, with a score of 2.0;

d) objectivity, with a score of 1.5 ;

e) critical spirit, with a score of 0.5 ;

f) the coherence between the lesson plan presented and the development of the class, with a score of 0.25 ;

g) the adequacy of the presentation to the established time, with a score of 0.25 .

At the UFC (by resolution No.10/CEPE/2009), the criteria for the teaching demonstration are: 
Sole paragraph. At the evaluation of the teaching demonstration each member of the committee of referees will assign his/her grade considering, preferentially, the following criteria:

a) coherence between the theme, the goals set out in the lesson plan and the developed contents;

b) mastery of content;

c) teaching performance and the appropriate use of time;

d) communication, clarity, relevance and objectivity;

e) structure of the lesson plan.

At the UFAM (by resolution No. 26/CONSUNI/2008), the following criteria are applied:

Article 42 - During the evaluation of the teaching demonstration the following criteria will be considered:

I. ability to organize and present ideas on the topic drawn;

II. objectivity;

III. mastery of the topic;

IV. coherence between the lesson plan presented and the development of the class;

$\mathrm{V}$. adequacy of the presentation to the established time.

The criteria are a precondition to render such examination a matter of discussion and a basis for legal action on the part of applicants. The criteria also democratize the practice because they make the basis of that practice mutually known. Moreover, and most important, they promote criticism and therefore the improvement of the practice. It is from the existence of such criteria that one may, for example, inquire the reason why "objectivity" appears as an item at two of the above universities. What kind of skill is objectivity? Why is it important? How can it be assessed? Observing the criteria of these three universities, one might also ask why one of them has weights for each item and the other two do not. The absence of weights makes it possible, for example, that a particular committee might, at any given time, see the adjustment of 
the class to the expected time, as an extremely important feature, though it is not so important actually. Could the applicant question that fact? No, because there are no weights.

Many aspects could be explored in terms of these three sets of criteria. I cannot deepen them here, but I would like to consider at least one of these aspects. What is the representation of teacher behind these criteria? Regarding this point, it is interesting to notice that both the UnB and UFAM's documents hardly present any mark of an explicit discourse about teaching. The examinations seem to serve much more to measure the knowledge of the applicant, although falsely, considering quite abstract and decontextualized skills: ability to organize ideas, ability to present ideas, objectivity. The UFC already contemplates, in a sense, certain specific aspects of the teaching practice, as demonstrated by the term "teaching performance". On the whole, however, its criteria still do not differ greatly from the other two universities; they are also loose, with the aggravating factor that they are not marked with weights. In all three universities, the examination appears more as a tool for assessing abstract knowledge (to make matters worse with fuzzy criteria), not for focusing on more specific aspects of the teaching practice.

My experience in five contests at UFSC (one in 2006 and four in 2009) tells me that it is exactly the teaching demonstration and the other oral-based tests that give the selection committee an absolute power over the practice of contests, protecting itself even further against questions, because what is not explicit cannot be questioned. In this context, the absence of criteria for assessing the teaching demonstration shows, I think, an asymmetry of power between those who are already members of the university teaching staff and those who want to become new members. It is as if the oral examinations had two natures: to the applicants they are sources of learning and ways to evaluate their performance (they have a pedagogical role), but to the evaluators they consist only of a professional practice of selecting professionals (a method of choice); as such, it makes any kind of feedback other than the final result unnecessary.

The questions raised by the Brazilian society regarding the contests, however, seem to have intensified in recent years. Thus, at the end of 2009, UFSC, for example, reworked its resolution for contests (which had remained virtually untouched since 1986 and had undergone 
only minor changes in 1992). In this new resolution, beyond the requirement that the teaching demonstration be recorded, there are criteria for its assessment, as follows:

Article 44. During the teaching demonstration, the committee of examiners will evaluate and score the candidate in terms of:

I - the mastery of the topic drawn;

II - the ability to organize ideas on the subject drawn;

III - the ability to present ideas on the subject drawn;

IV - the objectivity;

$\mathrm{V}$ - the coherence between the lesson plan presented and the development of the class;

VI - the adequacy of the presentation to the established time. (Resolution 01/CUn/2009). ${ }^{2}$

As I said above, the oral based examinations do not allow questioning by applicants and, therefore, favor a subjective and even personal choice by the committee, many times guided by hidden criteria, such as the department's intention to select a certain professional from a specific area, although the contest is, in terms of knowledge area, much broader. Going beyond this practical aspect, I believe it is possible, at this point of the explanation, by the emphasis given to the examinations based on oral performance, but particularly to the teaching demonstration, at least to raise the hypothesis that the representation of the professor best suited to Brazilian federal universities emphasize centrally the ability of oratory (I suppose in a popular sense) at the expense of knowledge and intellectual development that could be easily demonstrated in the curriculum, since it describes the history of the professional.

\footnotetext{
2 Besides the proposition of these criteria, the new resolution also covers ethical safeguards regarding the formation of committees of examiners, and, among them, the following can be highlighted: "Suspicion can be raised for a member of the committee of examiners who has a known friendship or enmity with any of the applicants or their spouses, partners, family and kin until the third degree" (art. 22, sole paragraph).
} 
This hypothesis becomes stronger if we consider the fact that it is very common, in the configuration of the contests (in terms of quantity and types of examinations), the occurrence of more than one test involving an oral presentation, all lifted to a higher level if compared to the scoring of titles. The oral skill, then, overrides the set of activities carried out by the professional in his/her career and thus overrides the history of that researcher.

It sounds contradictory that the scoring of titles is less valuable, since what is being done (the contest) is the selection of a scientist. Besides being the most objective examination, it is the one which allows checking the dedication, the prestige of his/her work among peers as well as in society, the set of contacts in academia, etc.

Several clues present in the analyzed materials also indicate that there is a very asymmetric power relationship between evaluators and evaluated. The apparently excessive number of examinations, many of them devised to evaluate the same capacity, is one of these clues. The greater the complexity attached to the practice and the higher the level of difficulty created, the higher the valuation effect of the position to which the selected candidate ascends. The evaluated party, in the environment of a public contest, is the outsider, who is less valued and therefore needs to submit him/herself. The degree of submission required, often excessive, gives a fair measure of the asymmetry built into this situation. A striking example of how this relationship occurs can be seen in resolution $37 / 2008$ of UFMS, which expresses the following:

Article 35. The teaching demonstration will consist of the presentation of a class, on the subject drawn, with a minimum duration of forty minutes and a maximum of fifty minutes.

$[\ldots]$

$\int 2$ The applicant will be eliminated if the time of his/her teaching demonstration is less than the minimum required.

$\int 3$ The applicant will be penalized in three points per minute over the time of his/her teaching demonstration in the grade of every member of the committee of examiners.

$\int 4$ The applicant will be stopped when reaching sixty minutes of presentation. (Emphasis added) 
In this excerpt the rigor of the "penalty" in three points per minute that exceeds the set time is particularly interesting. This rigor is completed by the second limit that is imposed to the applicant, who may exceed the time set out at a maximum of ten minutes. Certainly, this level of exigency which constitutes the genre and the practices of the contest establishes/represents a discourse on what it means to be a public servant in Brazil, what it means to be a teacher at a public university, and what it means to be a scientist.

\section{FINAL REMARKS}

This article aims to present some thoughts on genre analysis as a way to study the relationship between language and work. I also tried in this paper to contribute with an example of how a particular social practice, in this case the public contest for professors in Brazilian federal universities, can be analyzed in terms of a specific approach to the study of genres: Critical Genre Analysis.

The study reported here focuses only on a few aspects of the problem in question. The data collected, however, allows us to outline a hypothesis about the representation of professor which underlies public contests. Moreover, the documents which establish and regulate the contest enables us to verify, through the way the genres are conducted in this practice, the asymmetry of power between evaluators and evaluated, allowing further hypotheses on what this asymmetry means in terms of the discourses governing the practice of public contests.

Finally, we can see, even in an initial survey such as the one reported here, that the study of genre can contribute to understanding the discourses, the potential identities and the relationships established in a social milieu, thus becoming a tool for reflection about certain social problems. 


\section{REFERENCES}

AL-ALI, M. N. Religious affiliations and masculine power in Jordanian wedding invitation genre. Discourse \& Society, v. 17, n. 6, p. 691-714, 2006.

BARBOSA, F. G. Compreensão leitora em concurso público. 117 f. Mestrado (Dissertação em Língua Portuguesa)-Pontifícia Universidade Católica de São Paulo, 2008.

BAZERMAN, C. Systems of genres and the enactment of social intentions. In: ; MEDWAY, p. (Eds.). Genre and the new rhetoric. London: Taylor \& Francis, 1994. p. 79-101.

; PARADIS, J. (Eds.). Textual dynamics of the professions: historical and contemporary studies of writing in Professional communities. Madison, USA: University of Wisconsin Press, 1991.

BELTRÃO, C. F. Ensino de Língua Portuguesa: por uma educação linguística. 79 f. Mestrado (Dissertação em Língua Portuguesa)-Pontifícia Universidade Católica de São Paulo, 2006.

BHATIA, V. K. Towards Critical Genre Analysis. In: BHATIA, V. K., FLOWERDEW, J.; JONES, R. H. (Eds.). Advances in discourse studies. London: Routledge, 2008. p. 166-177. Interdiscursivity in critical genre analysis. In: BONINI, A.; FIGUEIREDO, D. C.; RAUEN, F. (Orgs.). Proceedings from the 4th International Symposium on Genre Studies (SIGET). Tubarão: Unisul, 2007. v. 1. p. 391-400. Disponível em:

$<$ http://www3.unisul.br/paginas/ensino/pos/linguagem/cd/English/36i.pdf $>$.

Worlds of written discourse: a genre-based view. London; New York: Continuum, 2004.

Analysing genre: language use in professional settings. New York: Longman, 1993.

BLYLER, N. R. Taking a political turn: the critical perspective and research in Professional communication. In: JOHNSON-EILOLA, J.; SELBER, S. A. (Eds.). Central works in technical communication. New York: Oxford University Press, 2004 [1998].

BONINI, A. Support, medium and hypergenre: genre and its relationships. 2009. (preprint version). 
As relações constitutivas entre o jornal e seus gêneros: relato das pesquisas do 'Projeto Gêneros do Jornal'. In: BRAGA, S.; MORITZ, M. E. W.; REIS, M. S.; RAUEN, F. J. (Org.). Ciências da linguagem: avaliando o percurso, abrindo caminhos. Blumenau: Nova Letra, 2008. p. 21-45.

DREW, P.; HERITAGE, J. (Eds.). Talk at work: interaction in institutional settings. Cambridge, USA: Cambridge University, 1992.

DEVITT, A. J. Intertextuality in Tax Accounting: Generic, Referential, and Functional. In: BAZERMAN, C.; PARADIS, J. (Eds.). Textual dynamics of the professions: historical and contemporary studies of writing in Professional communities. Madison, USA: University of Wisconsin, 1991.

FAIRCLOUGH, N. Analysing discourse: textual analysis for social research. London: Routledge, 2003.

- A Análise Crítica de Discurso e a mercantilização do discurso público: as universidades. In: MAGALHÃES, C. (Org.). Reflexões sobre a análise crítica do discurso. Belo Horizonte: Faculdade de Letras, UFMG, 2001 [1993]. p. 31-79.

FERREIRA, D. C. N. Aula de português no ensino médio: o processo de institucionalização de objetos gramaticais no trabalho docente. $147 \mathrm{f}$. Mestrado (Dissertação em Letras: Linguística e Teoria Literária)-Universidade Federal do Pará, 2008.

GEE, J. P.; HULL, G.; LANKSHEAR, C. The new work order: behind the language of the new capitalism. Boulder, USA: Westview, 1996.

GOFFMAN, E. Footing. In: RIBEIRO, B. T.; GARCEZ, P. M. (Orgs.). Sociolinguística interacional. Porto Alegre: Editora AGE, 1998 [1979].

HALL, C.; SLEMBROUCK, S.; SARANGI, S. Language practices in social work: categorisation and accountability in child welfare. London: Routledge, 2006.

JOHNSON, J. G.; KAPLAN, C. D. Talk-in-the-work: aspects of the social organization of work in a computer center. Sociolinguistic Newsletter, v. 10, n. 2, 1979.

LACOSTE, M. Fala, atividade, situação. In: DUARTE, F; FEITOSA, V. (Orgs.). Linguagem \& trabalho. Rio de Janeiro: Lucerna, 1998.

MARTINO, A. S. Coerência e coesão na interpretação de textos em provas de concursos públicos. 178 f. Dissertação (Mestrado em Língua Portuguesa)Pontifícia Universidade Católica de São Paulo, 2008. 
MOTTA-ROTH, D. Análise crítica de gêneros: contribuições para o ensino e a pesquisa de linguagem. D.E.L.T.A., v. 24, n. 2, p. 341-383, 2008.

NOUROUDINE, A. A linguagem: dispositivo revelador da complexidade do trabalho. In: SOUZA-E-SILVA, M. C. p. ; FAÏTA, D. (Orgs.). Linguagem e trabalho: construção de objetos de análise no Brasil e na França. São Paulo: Cortez, 2002. p. 17-30.

OSTERMANN, A. C.; SOUZA, J. Contribuições da análise da conversa para os estudos sobre o cuidado em saúde: reflexões a partir das atribuições feitas por pacientes. Cadernos de Saúde Pública (FIOCRUZ), v. 25, n. 7, p. 1521-1533, 2009.

SEGANFREDO, E. Da análise de questões sobre concordância em provas de concursos públicos a uma reflexão sobre normativismo e política linguística no Brasil. 258 f. Mestrado (Dissertação em Letras)-Universidade Federal do Rio Grande do Sul, 2003.

SILVA, S. B. B. A seleção do professor de português e suas relações com o ensino da escrita. Linguagem em (Dis)curso, v. 8, n. 2, p. 229-263, 2008.

SWALES, J. M. Other floors, other voices: a textography of a small university building. Mahwah, N.J.: Lawrence Erlbaum, 1998.

Recebido em 30/08/2010. Aprovado em 28/11/2010.

Título: A análise crítica de gêneros e a prática profissional: o caso do concurso público para professor em universidades brasileiras

Autor: Adair Bonini

Resumo: Várias abordagens têm sido utilizadas na análise da linguagem em situação de trabalho, dentre elas, a ergológica (LACOSTE, 1998; NOUROUDINE, 2002), a sociolinguistica interacional (DREW; HERITAGE, 1992), e a de gêneros textuais (BAZERMAN; PARADIS, 1991). Neste artigo, me atendo a essa última abordagem, discuto os motivos e os métodos de análise dos gêneros profissionais. Procuro me centrar em especial no que, mais recentemente, se tem denominado análise crítica de gêneros (BHATLA, 2004, 2007, 2008; MOTTA-ROTH, 2008). Como parte da reflexão teórica empreendida, realizo também uma análise inicial dos gêneros envolvidos na prática social dos concursos públicos para docente em universidades brasileiras, tendo por base uma série de documentos coletados e também minha experiência nessa prática. Esses concursos, à medida que põem em cena um problema da relação entre linguagem e trabalho, se revelam um excelente exemplo para se demonstrar uma análise critica de gêneros profissionais.

Palavras-chave: Gênero textual. Prática profissional. Análise crítica. Seleção de pessoal. Concurso público. 
Título: El análisis crítico de géneros y la práctica profesional: el caso del concurso público para profesor en universidades públicas brasileñas

Autor: Adair Bonini

Resumen: Varios abordajes han sido utilizados en el análisis del lenguaje en situación de trabajo, entre ellos, el ergológico (LACOSTE, 1998; NOUROUDINE, 2002), el sociolinguístico interaccional (DREW; HERITAGE, 1992), y el de géneros textuales (BAZERMAN; PARADIS, 1991). En este articulo, me atengo a ese último abordaje, discuto los motivos y los métodos de análisis de los géneros profesionales. Busco centrarme en especial en lo que, más recientemente, se ha denominado análisis crítico de géneros (BHATLA, 2004, 2007, 2008; MOTTA-ROTH, 2008). Como parte de la reflexión teórica empreendida, realizo también un análisis inicial de los géneros involucrados en la práctica social de los concursos públicos para docente en universidades brasileñas, teniendo por base una serie de documentos colectados y también mi experiencia en esa práctica. Esos concursos, a medida que ponen en escena un problema de la relación entre lenguaje y trabajo, se revelan un excelente ejemplo para demostrar un análisis crítico de géneros profesionales.

Palabras-clave: Género textual. Práctica profesional. Análisis crítico. Selección de personal. Concurso público.

BONINI - Critical genre analysis... 